\title{
S sciendo FCT сіинст
}

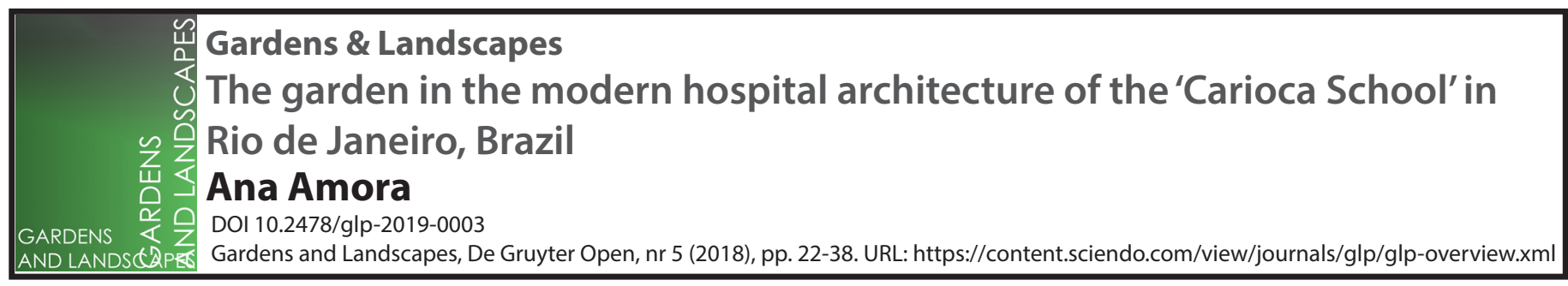

\begin{abstract}
The purpose of this article is to explore the role of gardens in the architecture of hospitals of the so-called "carioca school" of architecture, between the years of 1930 and 1960. In other words, to analyze gardens in the works of carioca architects who surrounded the architect Lucio Costa, or whose projects were influenced by the conceptions of this first generation of modern architects, who first graduated architecture school at the National College of Fine Arts and then, after 1945, at the National College of Architecture, in Rio de Janeiro.

The importance of gardens in the architecture of hospitals was mentioned in Edward Stevens's book "The American hospital of the twentieth century", in 1918, a publication which can be found at the UFRJ Architecture School library, as well as in the Brazilian doctors' book collections at the time. Stevens dedicates a chapter of this book to the landscape theme, where he states that the hospital designer and the landscape architect should work together.
\end{abstract}

On the other hand, Pasteur's discoveries and their implications in the management of hospital space did not occur without the mediation of landscaping. They resulted in changes when it came to choose the site for the hospital building within a city, as well as in its formal typology - from the Tollet model of pavilions, to the existence of green areas surrounding high buildings, and overlapping nurseries.

It is also relevant to bear in mind that public nationalist buildings played an important role after the revolution of 1930 in Brazil as they represented the state, and this resulted in significant projects.

We are therefore going to present four hospital buildings which were analyzed in our research on the integration of the Arts in the architecture of hospitals. Although the Lagoa Hospital, by Oscar Niemeyer, the Sanatorium Complex of Curicica, by Sérgio Bernardes, the IPPMG, by Jorge Machado Moreira, and the Souza Aguiar Hospital, by Ary Garcia Roza, all have different programs, formal typologies and links with their surrounding area, they are good examples for debating the presence of gardens in the Modern architecture of hospitals in the city of Rio de Janeiro. Three of these examples have fortunately included projects by landscape designer Roberto Burle Marx - the Lagoa Hospital, the IPPMG and the Souza Aguiar Hospital. The two former hospitals have had their buildings be surrounded by large gardens, in order to mitigate the harmful health effects related to the inclusion of 
hospitals within urban areas. The latter has been built in the 1960s with a complex program, in a dense historical area downtown, but adjacent to an urban park. It includes a vertical garden, which delimits, along with a panel in the hall (also by the same designer), a hallway for the user, between the urban and the healing space.

\section{Key words: Hospital Garden; Modern Hospital; Brazilian Architecture; 'Carioca School'.}

\section{ARTICLE}

\section{Introduction}

The purpose of this article is to explore the role of gardens in hospital architecture between 1940 and 1960, namely those designed by architects of the so-called 'Carioca School', comprising works of professionals working with architect Lucio Costa or those whose hospital projects were influenced by the conceptions of the first generation of modern architects. These were the first students to graduate in architecture from the National School of Fine Arts (Escola Nacional de Belas Artes - ENBA), in Rio de Janeiro, which in 1945 became the National School of Architecture (Faculdade Nacional de Arquitetura - FNA) ${ }^{1}$. Our aim is to show the existence of a landscape design tradition in the city of Rio de Janeiro that could be found in architectural projects designed by architects of the 'Carioca School' and served the purposes presented in the literature on hospital architecture that circulated within ENBA and FNA2.

This group of architects was named by writer and cultural activist Mario de Andrade ${ }^{3}$ as a 'school', the Carioca School ${ }^{4}$. Andrade, who validated the leading role of Rio de Janeiro's architecture- despite mentioning that the first manifestation of modern architecture occurred in São Paulo—- credited the creation of this 'school' by stating in 1944 that "what can legitimately be called the 'school' of modern architecture in Brazil is that of Rio de Janeiro, with Lucio Costa heading it" (XAVIER 2003: 177-181).

Through their design, these architects sought to build a complex alliance between responding to the needs of a health program, which would require extreme attention in its functional organization as a care-giving institution, and a quest to experiment with contemporary spatiality and art concepts using a modern outlook to re-create elements of the Luso-Brazilian colonial architecture.

\section{The Modern Hospital - its environment and typology}

The first modern references regarding hospital surroundings in Brazil mention the construction of new hospital buildings in the outskirts of cities $^{5}$, where the atmosphere would be pure and adequate to the patients' recovery. Assuring good air circulation was one of the conditions for the choice of a construction site. Temperature and humidity should also be considered as relevant aspects.

1 The institutions mentioned in the article had the names translated into English for clearer understanding, but the acronyms were kept in Portuguese.

2 We did not intend to study the therapeutic garden but rather the connection between architecture and gardens, which was fundamental in the relation of the modern carioca hospital buildings under study and the city, specifically in the conception of integrating arts in the overall construction work.

3 Mario de Andrade (1893-1945) was a poet, chronicler and novelist, critic of literature and art, musicologist, researcher of Brazilian folklore, and photographer.

4 Carioca is the name given to people who are born in the city of Rio de Janeiro, Brazil.

5 Cardoso (1930); Camargo (1930). 
The 1920s modernization of cities in Brazil, with its early verticalization and its consequences ${ }^{6}$, especially in the two largest cities - Rio de Janeiro, at the time the country's capital; and São Paulo, the capital of the most industrialized state - caused great controversy about the building typology of hospitals. On the other hand, Pasteur's findings affected hospital's spatiality, resulting in changes in the way the hospital building should be inserted in the city, as well as in its typology - from the Tollet model of pavilions constructed amid green areas to tall buildings with overlapping wards. In Brazil this happened with the mediation of the treatment of the surroundings and landscaping.

Seeking to choose the most suitable typology, engineer Vicente Licínio Cardoso made a study trip to the United States ${ }^{7}$, where he had contact with the new general hospitals built in a vertical block of several floors. Back in Rio, he wrote a book on the general modern principles of hospital hygiene and their application in Rio de Janeiro (CARDOSO 1930), in which he advocated the vertical block building as the appropriate typology. Following the Pasteurian theory of the moorings of the place, the argument that drives his book is that the hospital building should stand out in the city as a technical object and as a representation of the modernity that it intended to conquer.

In São Paulo, the architect and engineer Mauro Alvaro de Camargo, a civil servant of the state health service, expressed a different point of view in his book Hospital (CAMARGO 1930). His hypothesis on the best typology is less categorical, despite initially being favorable to the pavilion hospital type. From the analysis of the local context and the number of patients to be assisted, he sought a type that would better suit the situation.

Sharing his point of view, Rino Levi (IAB 1953: 39-42) denied an a priori definition of the formal typology of hospitals and stated that the design of the building could only be elaborated after the definition of the program. Therefore, any opposing initiative would be "inconvenient and a waste of time".

We consider that, among other reasons, the garden and the handling of the surrounding landscape in the modern hospital should play a mediating role between the urbanized city and the treatment site ${ }^{8}$. The garden would provide the most appropriate conditions of insolation, temperature, and ventilation for the patients' cure.

\section{Modern hospital architecture and the garden in the country's process of modernization}

The importance of gardens in the architecture of hospitals was mentioned in the book written by North-American architect Edward Stevens in 1918, entitled The American hospital of the twentieth century, a publication that was available at the library of FAU-UFRJ, as well as in collections of Brazilian physicians of that time, such as the ones of Carlos Chagas or Raphael de Paula Souza'. Stevens dedicates a chapter of his book to landscape, where he points out that the hospital architect and the landscape designer should work together.

Stevens (1918) states that the site should be taken into account in the construction of a hospital as a factor that would contribute to patients' recovery - namely the hospital's location and the physical characteristics of the environment in which it would be inserted:

There are greater possibilities for the care of the convalescent in suitably planned grounds around a hospital

6 Especially the rise of land value in most central areas, which had urban infrastructure.

7 The trip was in 1916, but the book was written in 1927 and published in 1930.

8 We consider that the tradition of using landscape design in gardens served the purpose of hospital architecture by creating a favorable environment for cure in modern urban architecture. This tradition also had an impact on other public buildings, anticipating the discussions held at the last meetings of CIAM (Congrès Internationaux d'Architecture Moderne); in this sense, Brazilian architecture was avant-garde. In the international sphere we highlight S. Gideon's work "Architecture, you and me - a diary of a development", published in 1958, although some texts had been written before WWII.

9 Available in the archives of Casa de Oswaldo Cruz - COC, at Oswaldo Cruz Foundation - FIOCRUZ. 
than within its walls; and when locating the building for a suburban hospital, special accessibility to the grounds should always be considered (STEVENS 1918: 228).

The architect writes not only about the land's orientation regarding insolation and ventilation, but also about its location in relation to industries and other polluting elements, its accessibility to the public and, finally, about the importance of landscaping around the buildings, since it can provide beautiful vistas and places of contemplation and rest as part of the treatment of the patients, while also contributing to the well-being of employees and visitors. The author dedicates a chapter to landscaping in the surroundings of hospitals, advising it should be the work of experts and architects devoted to this matter and recommending that: "If the outlook is depressing in one direction, it should be screened by a slight change in the location or by planting out the view" (STEVENS 1918: 229). The author gives examples of hospitals that he had visited in Europe, like the pavilion-type Virchow hospital in Berlin, as a model of coexistence and well-being.

In 1919, and following this perspective, the Brazilian engineer and architect Adelardo Soares Caiuby (CAIUBY1919), published a text entitled: The model leprosy project in the fields of Santo Ângelo, state of São Paulo (Projecto da leprosaria modelo nos campos de Santo Angelo, Estado de São Paulo). The idea of this model was to create a garden city with a picturesque atmosphere in which the architecture, with a country-like character in the middle of the green, would instill a feeling of familiarity and comfort in its users. As stated by the author: "The garden city becomes a solution to the problem. An immense park with tree-lined avenues, dotted with cheerful and picturesque little houses, all forming a small town" and "a large and picturesque park that surrounds all buildings, enhancing their charms" (CAIUBY 1919: 12-18).

A decade later, architect and engineer Camargo also refers to the quality of the surroundings of the hospital building and their importance in the recovery process. Regarding the landscape he claims that:

The enchanting joy of a landscape has upon our morals a greatly beneficial action, which, in turn, acts favorably upon our organism, just as the sadness of a corner of nature exerts something on us (1930: 10).

In the third chapter of the book, the author takes up the landscape issue presenting gardens as protection or cushion zones that provide less noise, a better climate and the ventilation of buildings, and he also refers to Edward Steven (CAMARGO 1930: 11):

Edward Stevens, after considering that hospital gardens or parks should be studied by a skilled landscape architect [...], mentions several North American establishments that are surrounded by famous parks: Newton Hospital, Talitha Cumi Maternity Home, Beverly Hospital, among others.

According to Alda Ferreira et al (2017), the garden landscaping tradition started to be built up in the eighteenth century. The Court's Public Garden (Passeio Público) was built during the Colonial period (1779-1783) by Valentim da Fonseca e Silva and it reflected a way of seeing the city's landscape that associated the city's way of life with a 'taste' for landscape layout. This trend lasted throughout the nineteenth century, with the creation of public institutions and the participation of European naturalists and landscape designers as Court's officials - until 1822 it was the Portuguese Court; then the Brazilian Court $^{10}$. This situation continued into the Republican period ${ }^{11}$, and at the beginning of the twentieth century the Frenchman Paul Villon became the first professional to formally adopt the title of landscape architect, as head gardener of Rio de Janeiro's Inspectorate of Land and Sea, Forests,

10 In 1839, the German naturalist Ludwig Riedel was appointed director of the Botanical Garden of the Public Walk. In 1861, the Frenchman Auguste François-Marie Glaziou was appointed for the direction and conservation of the Public Walk and in 1869 he was appointed Director of Parks and Gardens of the Imperial House; later he was appointed Inspector of Municipal Gardens (Ferreira et al 2017).

11 The Brazilian Republic, which overthrew Emperor Pedro II, was proclaimed on November 1889 by the Republican movement, led by army officers. A 'Provisional Government' was established, headed by Marshal Deodoro da Fonseca. 
Hunting and Fishing.

The Revolution of 1930 and the first Getúlio Vargas' federal administration (1930-1945) ${ }^{12}$ fostered the country's modernization, as well as improvements in the field of education and the ones of architecture and urbanism. In this period, health played a prominent role with the creation of the Ministry of Education, Health and Public Assistance and the construction of hospitals and health centres, as well as other buildings necessary to the functioning of the structure of public health. Subsequently, during the so-called democratic period that lasted from 1945 to 1964, the creation of the Ministry of Health in 1953 ensured the autonomy of measures adopted in health policies.

Lucio Costa was appointed director of ENBA in 1930, enhancing the modernization of architecture and urbanism. His term lasted only for a short period of time ${ }^{13}$, during which he promoted the updating of the course. In addition to hiring teachers who supported a modern conception of architecture, Costa instituted a curricular reform by assigning the General Course a modern character through the encouragement of a new pedagogical regime. It consisted of a broad development of both technical and scientific education with the introduction of the subjects of urbanism, landscape architecture and techniques into the course syllabus, together with the mandatory requirement for practical works (FERREIRA et al 2017).

An expansion of public services and the consequent increase of public buildings construction works led to the creation of jobs for a considerable number of professionals.

In addition, with its inclusion in the curriculum established by Costa's reform, landscape design — until then restricted to agronomy and gardening-, became a subject of interest to architecture and urbanism. Therefore, according to Ferreira et al (2017), the teaching of landscape architecture was not an isolated fact, but rather a social-historical process, resulting from a habitus that had been constructed for over a century in the city and had favored it.

\section{Four modern hospitals in Brazil}

In this section we will present four hospital buildings that are being analyzed in an ongoing research about the integration of the arts in hospital architecture: the Lagoa Hospital (Hospital da Lagoa) by Oscar Niemeyer; the Curicica Sanatorium Complex (Complexo Sanatorial de Curicica) by Sérgio Bernardes; the Martagão Gesteira Child Care and Pediatrics Institute (Instituto de Puericultura e Pediatria Martagão Gesteira - IPPMG) by Jorge Machado Moreira; and the Souza Aguiar Hospital (Hospital Souza Aguiar) by Ary Garcia Roza. Although these hospitals have different architectural programs, formal typologies, and relation with their surrounding areas, they are significant examples for the discussion on the presence of gardens in modern hospital architecture in the city of Rio de Janeiro between the late 1940s and the 1960s.

I argue that their landscape design follows Lucio Costa's design of the 'casas sem dono' (houses without owners) (1933-1936), his first reference to the idea of a tropical landscape and its relation to architecture. They were designed as an exercise of free creative work for a modern type of home, in this case for the tropics' dwelling, one where the architect put telluric poetics into practice (BRITO 2014). These houses have gardens built into covered areas through pathways and places for contemplation and leisure. Presenting a rationalistic language influenced by

12 An armed political-military movement, with a nationalist and modernizing character, which determined the end of the so-called Ancient Brazilian Republic (1889-1930). This movement had its origin in the alliance between politicians and lieutenants defeated in the elections of 1930, in which Julio Prestes was chosen as the oligarchies' representative. The following government, led by Getulio Vargas, had three different moments: Provisional Government (1930-1934); Constitutional Government (1934-1937); New State, dictatorial (1937-1945).

13 Lucio Costa was dismissed on September 18, 1931, after one year in that position. 
the Corbusian repertoire, the design of these houses demonstrates a Brazilian way of seeing the modern dwelling, in which the garden plays a leading role, and we can even point out that this was a rehearsal for a way of producing architecture that inspired the architects mentioned above.

Several issues should direct our attention to the hospitals we intend to describe. What is the role of the garden as an interface between the environment and the building? How does garden design relate to building design? What are the formal intentions of the authors in creating this landscape around hospital buildings? What do these spaces look like today and how are they used in the daily life of these institutions? Three of these examples have fortunately received projects by Brazilian landscape designer Roberto Burle Marx - the Lagoa Hospital, the IPPMG, and the Souza Aguiar Hospital; however, we will start with the Curicica Sanatorium Complex.

\section{The Curicica Sanatorium Complex}

The Curicica Sanatorium Complex was inaugurated in 1952 and it is among one of the early works by architect Sérgio Wladimir Bernardes (1919-2002), who graduated in 1948 as part of the second generation of Carioca's architects from the then National School of Architecture (Faculdade Nacional de Arquitetura - FNA), at the University of Brazil (Universidade do Brasil), now the Federal University of Rio de Janeiro (Universidade Federal do Rio de Janeiro - UFRJ). Shortly after his graduation, Bernardes became head of the Architecture Department of the National Campaign Against Tuberculosis (Campanha Nacional Contra a Tuberculose - CNCT) of the National Tuberculosis Service (Serviço Nacional de Turberculose - SNT).

The architectural program of the Curicica Sanatorium Complex adopted the technical assumptions developed by the SNT, previously approved by the Ministry of Education and Health, and the general recommendations followed the study and standardization of the construction of 'campaign type' sanatoriums and dispensaries, as it was expected that the disease would be eradicated within a few years: efficiency, low cost and economical maintenance,

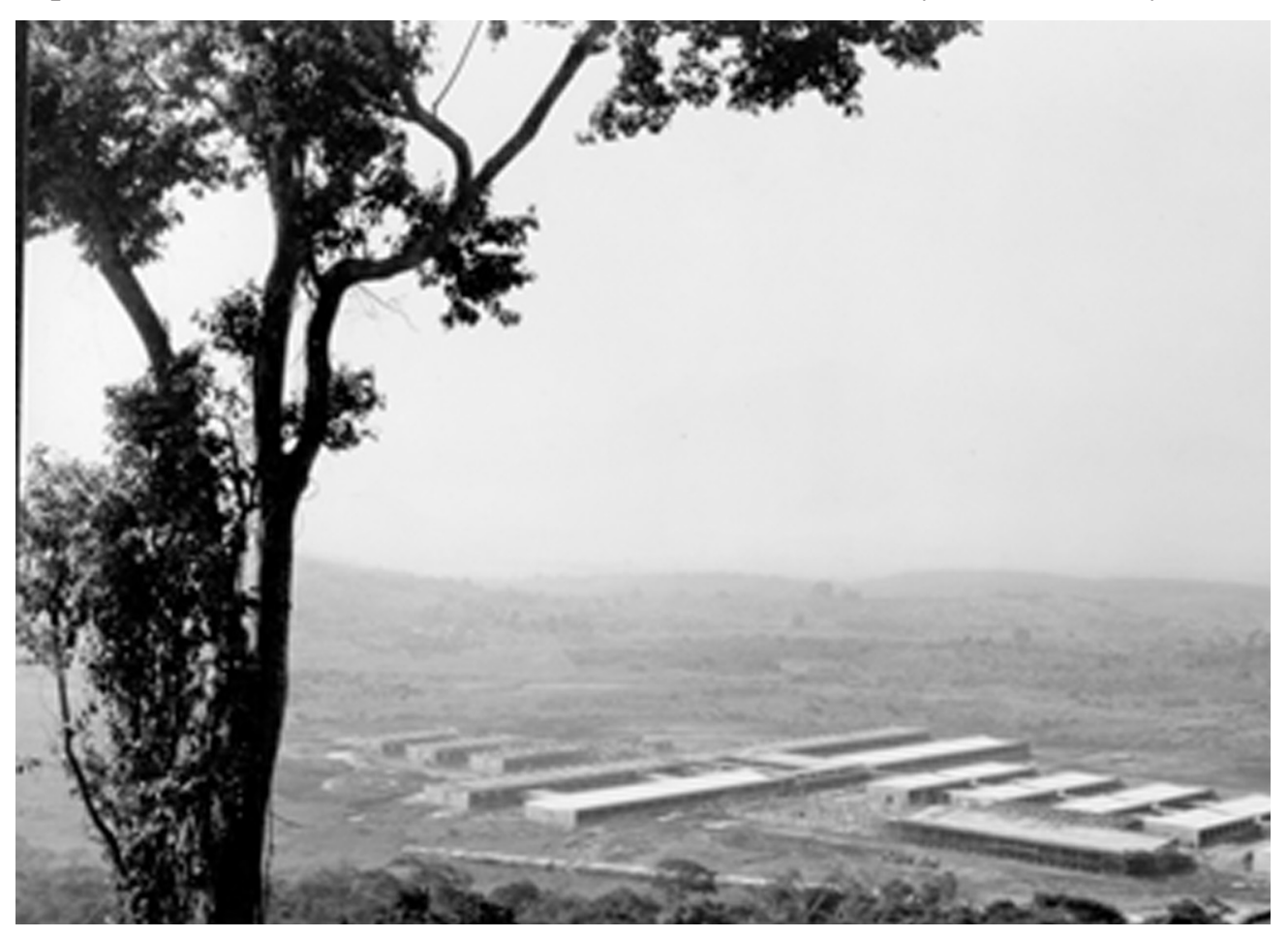

Figure 1. Curicica Sanatorium under construction. Raphael de Paula Souza Fund, DAD/COC/FIOCRUZ but also ensuring technical and functional qualities. Although at that time the Monoblock system was already fully in use in hospital architectural design, the one adopted was that of pavilions, more suitable for the treatment of certain diseases, such as pulmonary tuberculosis, mental illness, and leprosy, since it allowed for a better isolation of patients according to the varying degrees of the disease, up until they were able to return to society. According to Lourival Ribeiro ${ }^{14}$, evidence

14 Lourival Ribeiro da Silva (1907-1992) was a Brazilian physician who specialized on tuberculosis. He held various positions in the healthcare field, including the administration of Curicica Sanatorial Complex (1953) and the direction of the National Service of Tuberculosis - SNT (1956-1958). He was also the president of the Brazilian Society of Tuberculosis from 1952 to 1954 and a professor of Pneumology and Pathobiology at several medical schools in the country. 
shows that the high percentage of incarceration of patients admitted led the architect to grant Curicica with special characteristics in order to avoid the negative impact of confinement (COSTA et al. 2002).

Its location in a widespread area, distant from Rio's city center, allowed for the option of the pavilion typology; the plan of the complex, with its geometric formality, contrasts with its surroundings at the time of its creation, as it was partially enclosed by the Atlantic forest and partially by a rural area presenting no signs of urbanization. This contrast served the symbolism of this monumental insertion of the presence of the State in the area, as it provided visibility and grandeur to the hospital, despite its linearity and low height.

The original program included not only an area intended for the hospitalization of patients and other related services, but also a research area and housing for medical and administrative staff. Thus, the first remark is that the functional division is still currently under the administration of two distinct institutions: one is the Raphael de Paula Souza Municipal Hospital; the other one is a research area of the National School of Public Health (Escola Nacional de Saúde Pública - ENSP) of Oswaldo Cruz Foundation (FIOCRUZ). The axis that separates these two areas at the main entrance of the complex is also the one of great magnificence, with a lake surrounded by high trees.
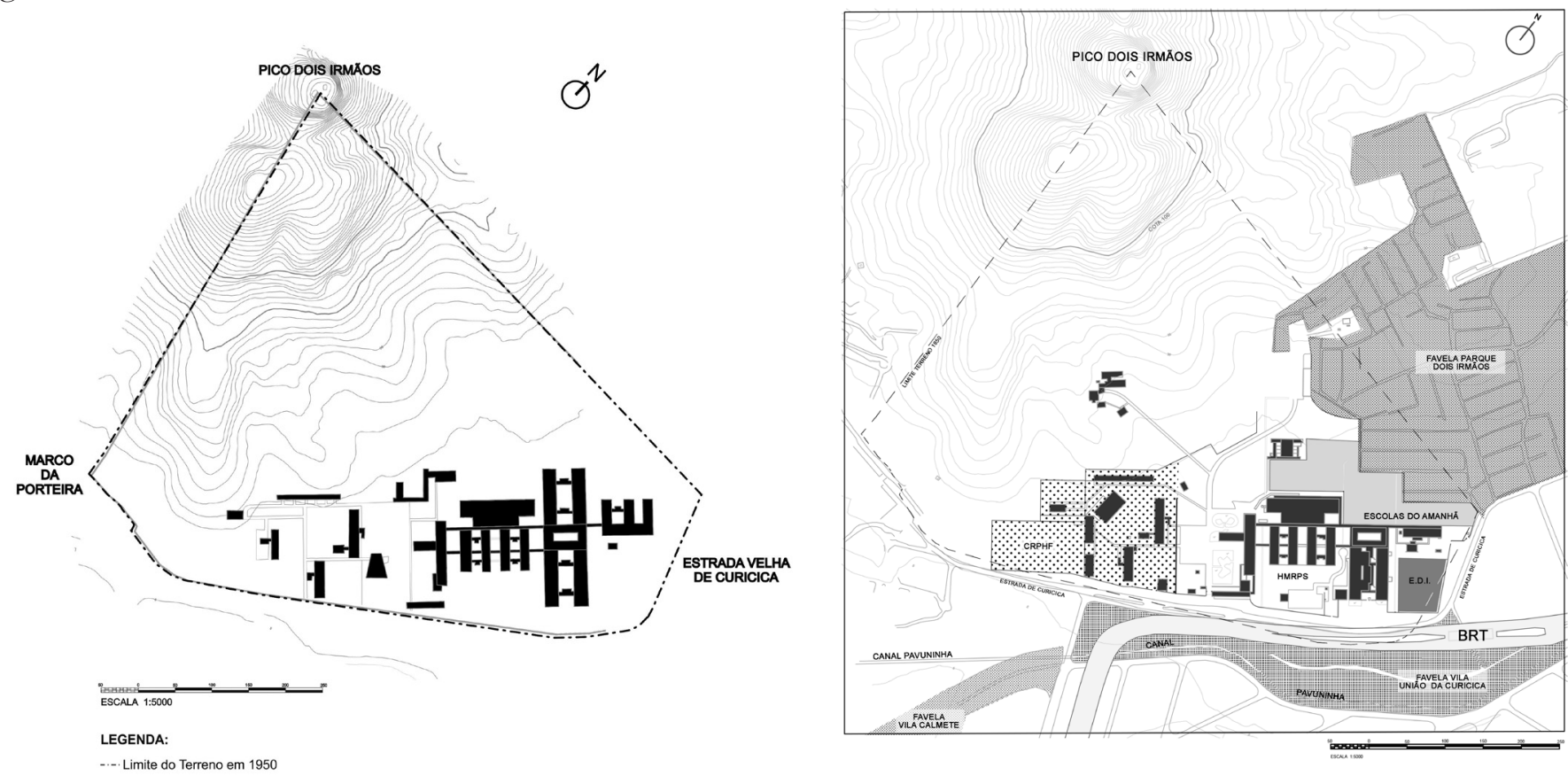

Figures 2 and 3. Curicica Sanatorium site plan-original plan and current situation. LabLugares/PROARQ/FAU/UFRJ (drawing by Michael Morouco, 2016).

The buildings are connected by passages that are covered and laterally enclosed by cast ceramic elements, as an interpretation of the 'muxarabi' $i^{15}$ used in Luso-Brazilian colonial architecture. The pavilions are interspersed with landscaped courtyards of the same size and with a floor design that refers to the modulation.

After the construction of the Curicica Sanatorium was completed it was observed that landscape planning was needed. The landscape architect Costa Neto accepted the assignment and conceived the landscaping project for the complex ${ }^{16}$.

15 Of Arabic origin, mushrabeyeh (spelling according to Oxford Dictionary of Architecture. Oxford, UK: 2000, p. 442; in Portuguese, 'muxarabi'), refers to timber latticework placed in front of windows to obtain shade and privacy. It was common in Portugal during the historic Al-Andaluz period and it became an architectural feature of the city of Lisbon until the sixteenth century. This architectural element was taken from Portugal to Brazil.

16 In an interview (October 11, 2017) held by the research team with Alexandre Costa Neto's daughter Lúcia Costa, a landscape architect and professor at PROURB - Postgraduate Program in Urbanism (Programa de Pós-Graduação em Urbanismo), she mentions the informality of the request made by the head of the architecture department, Sérgio Bernardes, who asked: "Can anyone do this project?". According to Lúcia, Costa Neto stated that the Curicia project had defined his career option as a landscape architect. 



Figures 4 and 5. Lake by the main entrance. LabLugares/PROARQ/FAU/UFRJ (2016).

An interesting aspect of this landscaping project, besides the splendor of the entrance and the creation of a pleasant atmosphere between pavilions and pathways, is that it mediated the extensive area of the sanatorium in relation to the surroundings that were not yet urbanized and the preserved Atlantic forest in its Northeast limit. It clearly meets the treating of open spaces in sanatoriums with gardens as a premise to promote the patients' well-being and act in favor of their healing. ${ }^{17}$

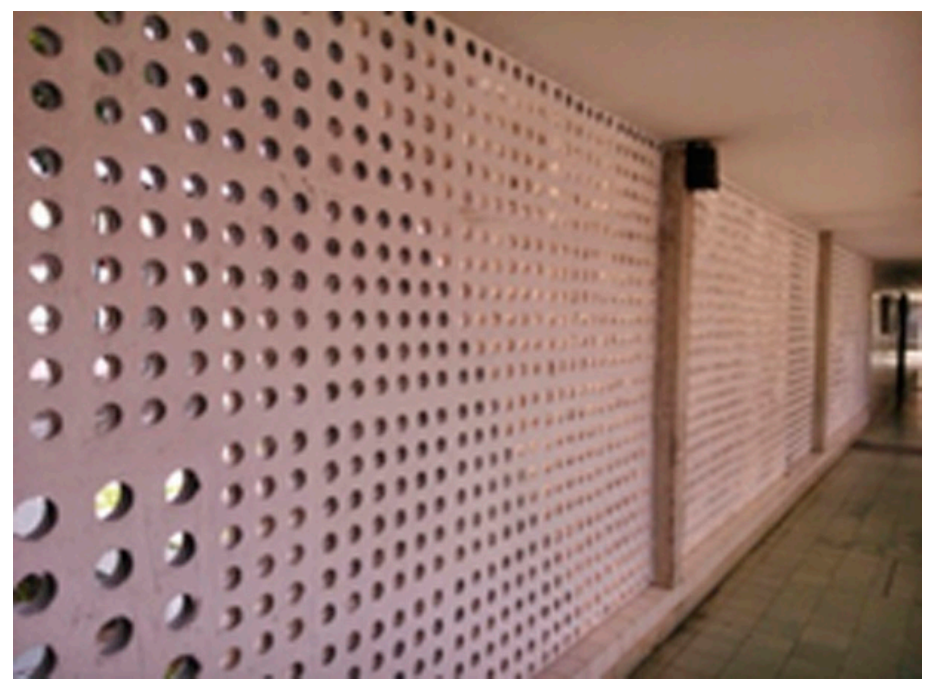

Figure 6. Covered passages with side closure with hollow elements (combogós). LabLugares/PROARQ/FAU/UFRJ (2014).

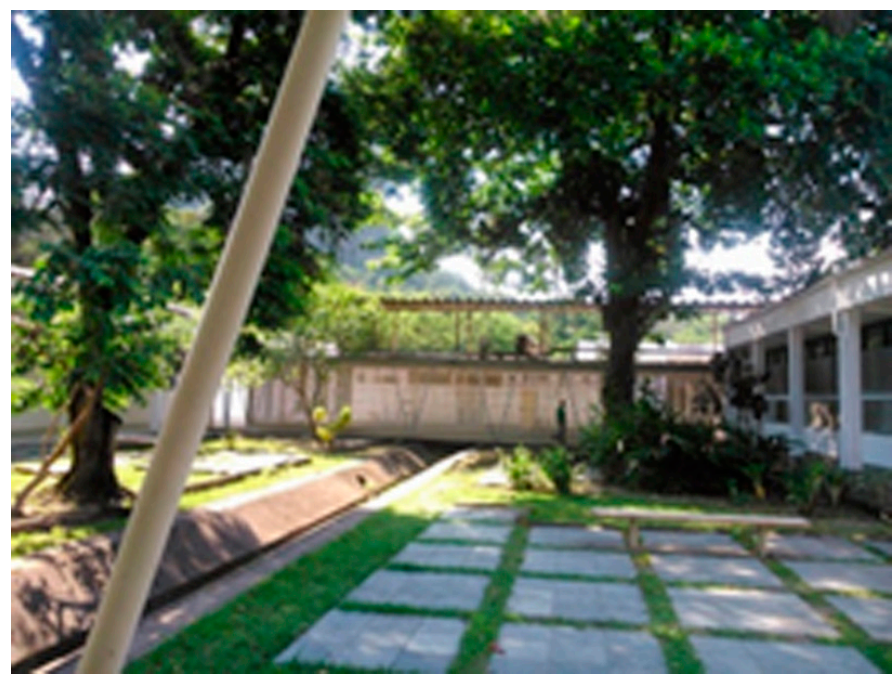

Figure 7. Courtyard between pavilions. LabLugares/PROARQ/FAU/UFRJ (2014).

Since then, the area where Curicica is located has undergone an intense urbanization process and part of its surroundings are presently occupied by low income communities, the so-called favelas, and by mass transportation corridors, the Bus Rapid Transit - BRT. This has had an impact on the sanatorium complex, with part of its area being invaded by a favela and pavilions having been demolished for the construction of public equipment to meet the demand of these communities and of the city ${ }^{18}$.

17 Unfortunately, however, we did not find the projects and plans of these CNCT's hospital gardens in our research. We can infer that there was urgency for the construction and inauguration of the sanatoriums, aiming at the eradication of the disease, thus the landscape work was necessary but there was not enough time for more elaborate projects. We thank Thaysa Malaquias for her research.

18 This affected the sanatorium concerning both the built spaces and the open garden spaces, and, consequently, the relation between the architectural design and the landscaping idealized by the architects. 


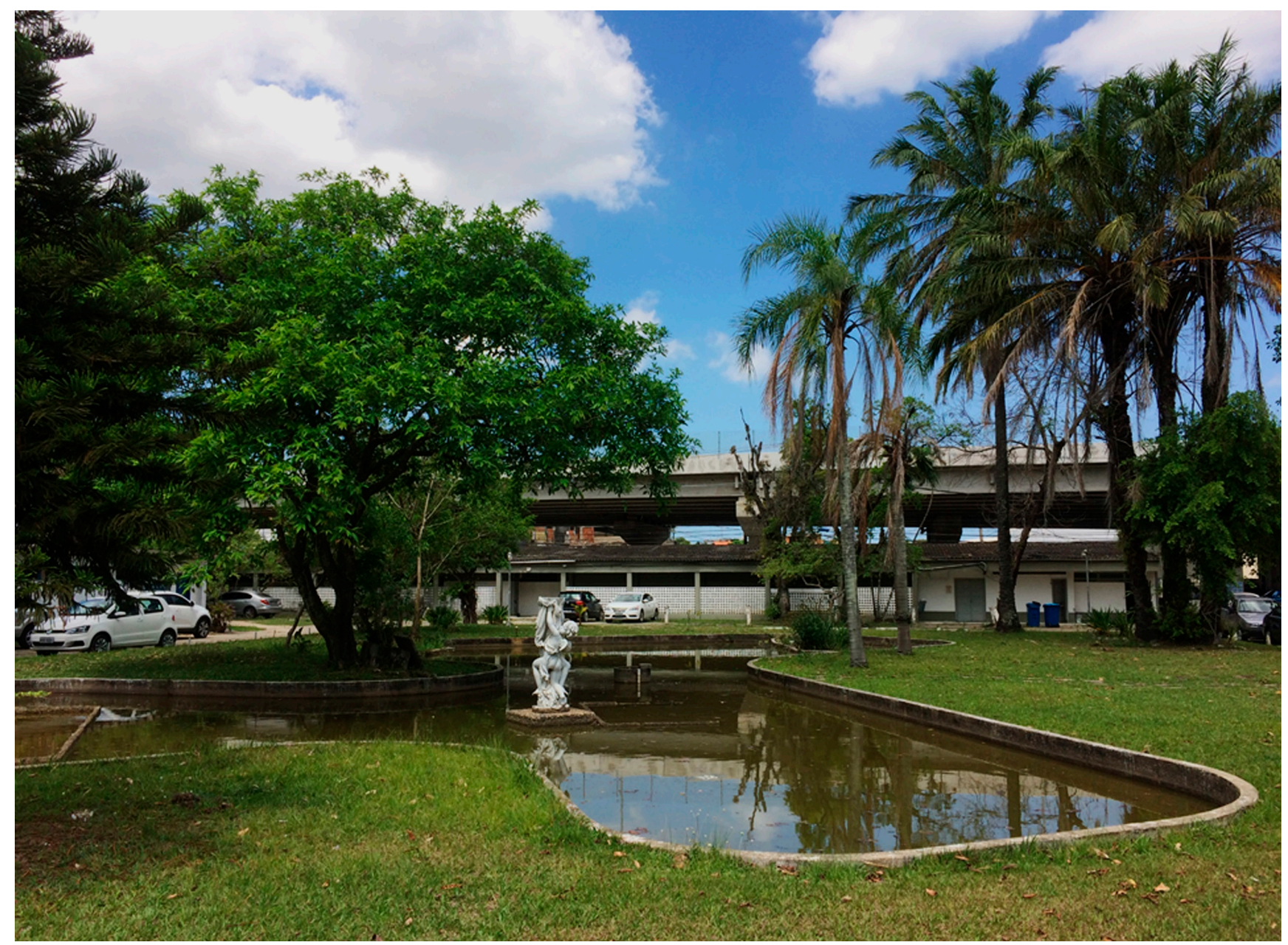

Figure 8. The main entrance with the BRT viaduct in the background. LabLugares/PROARQ/FAU/UFRJ (2016).

\section{The Martagão Gesteira Child Care and Pediatrics Institute}

The Curicica Sanatorium Complex was built in the same period of the award-winning ${ }^{19}$ project of the Martagão Gesteira Child Care and Pediatrics Institute (Instituto de Puericultura e Pediatria Martagão Gesteira - IPPMG), designed by architect Jorge Machado Moreira (1904-1992) and implemented between 1949 and 1953 within the Technical Office of the University of Brazil (Escritório Técnico da Universidade do Brasil - ETUB). In 1949, Jorge Moreira was invited to be the chief architect of ETUB and he was given the mission of planning the University City (Cidade Universitária). His only requirement was the freedom to choose his collaborators, who should endorse his design concepts. In that same year he began the development of the IPPMG project.

According to Paulo Jardim (RODRIGUES at al. 2013: 24-32), the work of Jorge Moreira is marked by a design process that is guided, from the location to the final details, by rationalist and functionalist principles; IPPMG was the most eloquent expression of this way of thinking and producing architecture. In this context, according to the author, the architect used two specific resources in his design method: the strategy of conciliation between constructive technique and space arrangement adopted by the modern German school of Walter Gropius and Mies van der Röhe; and the aesthetics acquired in the study and experience with architect Le Corbusier. As in Curicica, a grid defines not only the position of the pillars, but also the closing panels, mullion pillars, lighting fixtures, the rhythm of the facades, and the pagination of floors and walls.

19 First prize in the category of hospital buildings in the 2nd São Paulo Architecture Biennale, receiving from the jury the mention of outstanding model work. Two years later, it has become a part of the catalog of the exhibition Latin American Architecture since 1945, resulting from the homonymous exhibition at the Museum of Modern Art in New York organized by Henry-Russell Hitchcock in 1955. 


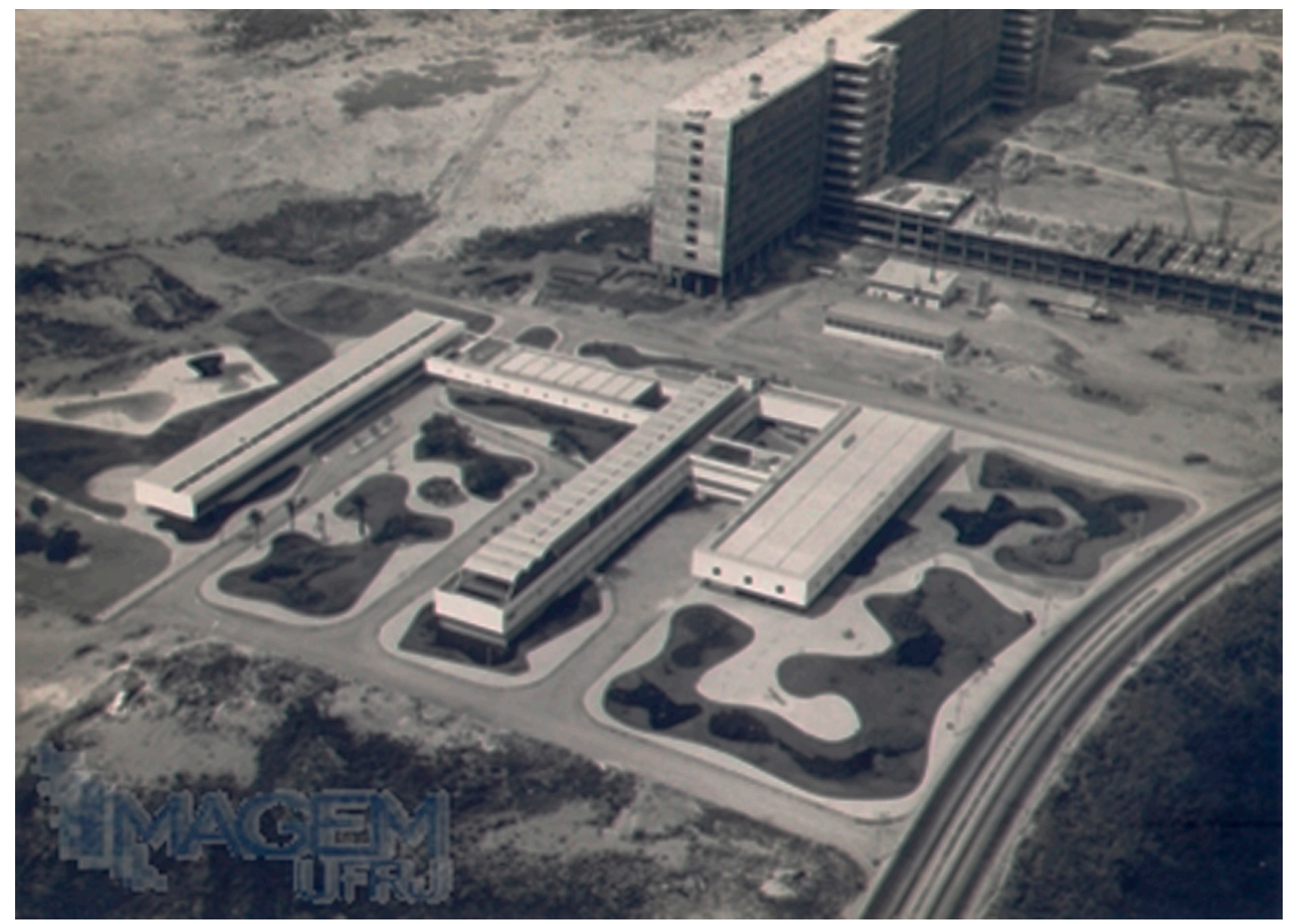

Figure 9. IPPMG in the foreground, with the University Hospital under construction in the background. ETU/UFRJ.

The IPPMG location, nearby other health functions of the campus and close to its main entree, facilitated at that time the access of patients and those who accompanied them. The buildings' reduced height had as presupposition the small amount of necessary beds and it was also intended to highlight the General University Hospital building (Barboza and Moreira 1952), currently Clementino Fraga Filho University Hospital (HUCFF), which was designed in large size and height for a number of attendances that was never reached, and to stand as a landmark of the University City.

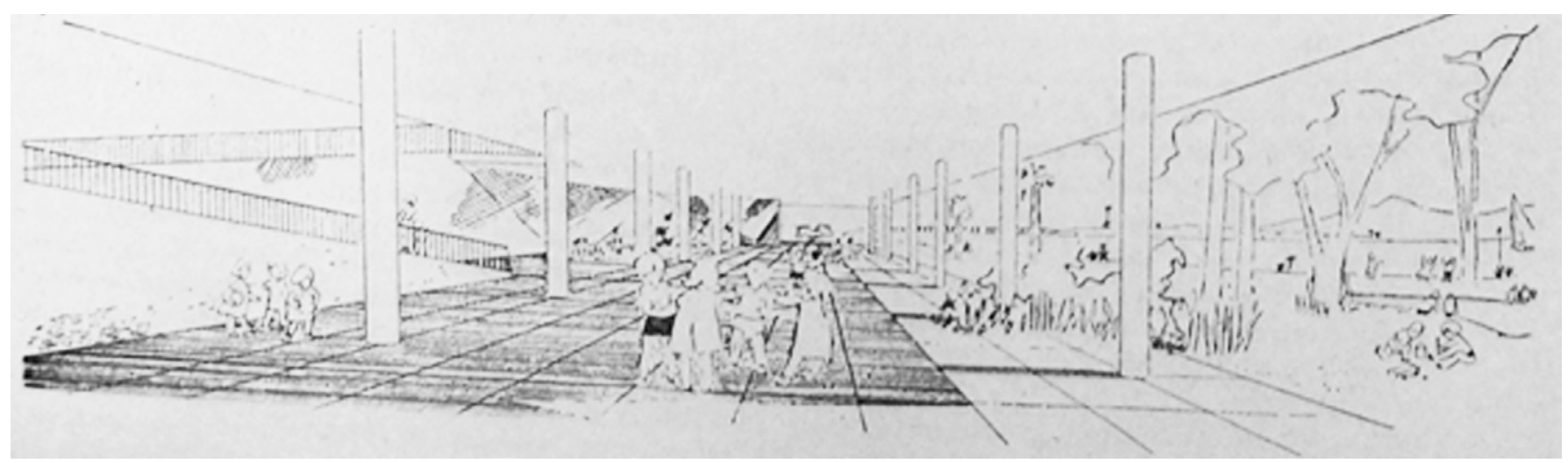

Figure 10. Drawn by the architect: child recreation area with garden at the pilotis. Barboza and Moreira, 1952.

The IPPMG presents a formal typology in pavilions, arranged in a comb type, composed of three blocks interconnected by a fourth building, to house a program dedicated to maternity and child care. To comply with the 
program prepared in conjunction with the director, physician Joaquim Martagão Gesteira ${ }^{20}$, to house the facilities of care for both healthy and sick children, the architect opted for their distribution in two sectors (pavilions), independent and distant from each other. The distance between these buildings is such that it allowed the use of an interconnecting section for auxiliary services.

The Hospital and the Ambulatory sections were designed for patient care, and they were located in the area closest to the main access to the Fundão Island, at the time. The Ambulatory was partially designed on pilotis and it is the pavilion that is most visible from the main access; on the upper floor there are offices and other shared services with the Hospital. The Hospital stands out as an element of greater height, with a third floor; the ground floor is used for general services and the institution's administration offices. On the third floor, in addition to management facilities, there is a solarium for hospitalized children that was built using concrete vaults. It presents an aesthetic appeal and it crowns the complex.

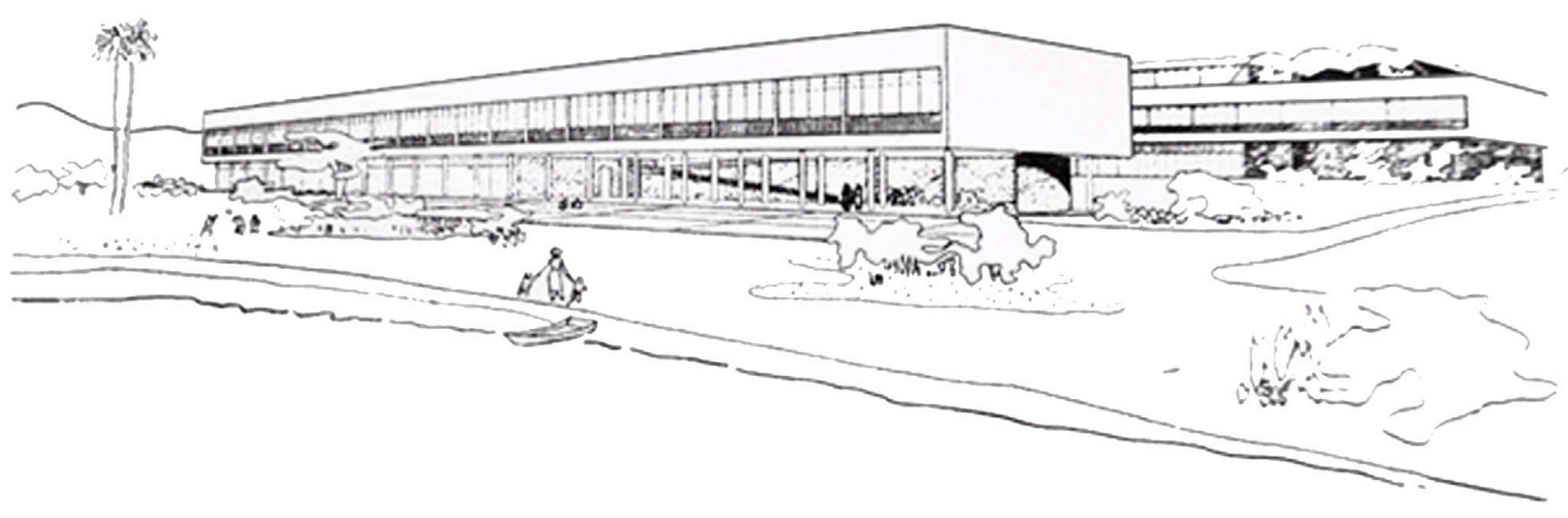

Figure 11. View of Child and Maternity Shelter. Barboza and Moreira, 1952.

The Child and Maternity Shelter, designed in the same building and parallel to the Hospital, was located on the opposite side, taking advantage of the inclination of the ground as to facilitate the view from the hospital wards towards the coastal landscape (BARBOZA and MOREIRA 1952). The ground floor houses the general services of the sector and it has a large covered area for children's recreation amidst the garden.

For the area designed for auxiliary services and the milk bank, which links the two sectors, the architect sought to make use of the topography by connecting the ground floor of the Hospital to the second floor of the Child and Maternity Shelter.

Around the set of pavilions, a new landscape was created by Roberto Burle Marx, guided by the architect's intention. Originally, to articulate the complex of IPPMG pavilions with its environment, a first larger garden was designed to fulfil the role of welcoming the users, as a counterpoint to the inhospitable surrounding landscape - remnants of coastal vegetation and landfills. Then, a smaller internal garden was planned to separate the two sectors and allow the permanence of this local atmosphere. In the sequence, small patios and landscaped inner courtyards aimed at providing ventilation and lighting. Near the sea, in the extension of the pilotis of the Child and Maternity Shelter, the architect idealized a poetic relation with the water's edge, as can be seen in his own hand drawing.

20 Joaquim Martagão Gesteira (1884-1954) was a Brazilian physician, writer, teacher, philanthropist and public manager in the area of child health. 
According to Lucia Costa (RODRIGUES et al. 2013: 34-36), as in the other partnerships between Burle Marx and Jorge Moreira, sinuous flowerbeds are present in a marked counterpoint to the buildings' orthogonality, with the predominance of lawns as support to groups of vegetation, composed of 77 species, interspersed with Portuguese stone floors and concrete benches. Sets of tall trees and palms were proposed to bring a vertical contrast with the horizontality of the buildings, and the existence of a small park in front of the Child and Maternity Shelter was designed to have a different landscape treatment by means of lawns, sand and gravel, and the Portuguese stone floor at the pilotis area. There were also tile panels throughout the buildings, of which the one that marks the Milk Bank entrance stands out.

Despite the integrity of the original shape and the preservation of most details, the ensemble suffered mutilations over time, with significant impacts on the gardens, such as the suppression of part of them, closure of areas where there were permeable spaces with pilotis, and additions made of an urgent nature. In the latter case, the garden of the inner area between the Child and Maternity Shelter and the Hospital has been increasingly used as a parking lot, sidewalks and flowerbeds included. The courtyard between the Ambulatory and the Hospital was occupied by ship containers used as emergency facilities for storage, but fortunately these can be removed. On the garden terrace the flowerbeds have been suppressed and the concrete vaults have been closed, thus modifying the architectural and landscape concepts.

The urban interventions in the surroundings were the most harmful factors to the gardens that demarcate the site. Between 1992 and 1994, the construction of RJ 071 (the 'Red Line') led to the suppression of part of the external garden area; and in 2010, the university campus bus station was built on another part of the garden. More recently, the implementation of the nearby BRT terminal and the construction of a strip for the circulation of these buses between the 'Red Line' and the buildings led to the suppression of another part of the garden.

Another factor that has contributed to the aggravation of the preservation conditions of this priceless testimony of the relationship between gardens and hospital architecture, there is a lack of maintenance of the IPPMG buildings and the entire UFRJ Campus. Roberto Conduru (1999) considers that IPPMG has resisted all these adversities, remaining reasonably intact, thanks to the quality of the project in terms of detail, planning and construction.

\section{The Lagoon Hospital}

The hospital currently known as the Lagoon Hospital (Hospital da Lagoa), officially named Lagoon Federal Hospital (Hospital Federal da Lagoa), is located in the neighborhood of Jardim Botânico, in the Southern area of Rio de Janeiro. The original project was designed by architects Oscar Niemeyer (1907-2012) and Hélio Uchoa (1913-1971); construction works started in 1952 and they took seven years before their completion in 1959.

The institution was created and built by the Larragoiti Foundation and its first denomination was SulAmérica Hospital $^{21}$. In 1962, the hospital was acquired by the former Bank Workers Retirement and Pensions Institute (Instituto de Aposentadoria e Pensões dos Bancários - IAPB), with the permission of President João Goulart. On this occasion it was named Bank Workers Hospital, as part of the health care support promoted by the bank workers' union. In November 1966, retirement and pension institutes that provided services for private sector workers were extinguished and the assistance to workers was unified under the National Institute of Social Security (Instituto Nacional de Previdência Social - INPS). Later, the hospital was integrated into the network of the former Social Security National Institute of Medical Assistance (Instituto Nacional de Assistência Médica

21 South-America Hospital, from the South America Insurance Company (SulAmérica Seguros). 
da Previdência Social - INAMPS), which later had its health care network transferred to the Ministry of Health.

The architectural design was planned by Niemeyer and Uchoa had the landscaping project be idealized by Roberto Burle Marx and the tile panels by artist Athos Bulcão. The complex has three blocks: the hospital building, the ambulatory building, and the chapel; the hospital and the chapel are part of the original plan. Around and connecting them, gardens were designed to create a 'specific site' in the neighborhood, which was being urbanized at the time. In addition, the existing landscape that surrounded the building site, with a view to the Rodrigo de Freitas lagoon on the one side and the mountains on the other, was certainly taken into consideration by the architects and the landscape designer. Presently, the neighborhood is entirely urbanized, and the streets function as arteries to the intense traffic that moves towards the Western area of the city, which is its most recent area of urban expansion, so that the hospital gardens act as a protection barrier from this environment.

The construction process met several setbacks. The first one was the need to remove a low-income community - a favela with approximately 1,000 residents - that occupied the construction site ${ }^{22}$. Another problem was the soil's characteristics, configured as a swampy terrain that required special care in the elaboration of the architectural design, which included an underground floor.

The Lagoon Hospital was listed in 1992 by the State Institute of Artistic and Cultural Heritage (Instituto Estadual do Patrimônio Cultural - Inepac). When one analyses only the main building of the hospital it can be considered as an example of the typology, in a vertical block, that represents the repertoire of the 'Carioca School' due to the integration of arts - architecture integrated with gardens and mural art, as well as brise-soleil and ceramic elements (combogó) for solar protection, which recreates the historical 'muxarabis' from Brazilian modern architecture.

The main building that houses the hospital is a ten floors high rectangular bar block resting on a ' $\mathrm{V}$ ' shape pilotis ${ }^{23}$. In this building there is the predominance of horizontality, despite its height, and it is crowned by irregular elements that house infrastructure services and a real slab that was originally meant to house a roof garden that has never been built. The building runs parallel to both to the main street (Botanical Garden Street) and to the shore of the Rodrigo de Freitas lagoon, dividing the building site into two parts.

In the first part of the building site there is the main entrance, from Oliveira Rocha street. From this entrance, the garden opens up to a curved paved esplanade towards the main door of the hospital block, delimited on the right side by an island of vegetation with a lake that also presents a curved shape. Patients and visitors use this pathway to reach the main building using the ground floor in the corner of its Northwest side, which is slightly raised in relation to the garden. In the Western part of the site, perpendicular to the main building, there is the ambulatory ${ }^{24}$ block, where the users' entrance is made independently through the Jardim Botânico street; the border of the building site with the street sidewalk was treated with vegetation, lessening the effects of the street noise.

On the Eastern side of the building site, next to the facade of the main building, another edifice was built, originally designed as the hospital's chapel. This part of the site is more intimate, facing the Rodrigo de Freitas lagoon. A set of ramps, from where one can enjoy the view over the garden, connects the 'chapel' to the main building. This garden has a special design; on the opposite side of the lake, near the 'chapel', there is a small plaza surround-

22 The removal of the so-called Hipica Favela, or Vila Hipica, near the neighborhood's hippodrome, was the aspect that caused the most delay in the hospital's initial works. The location of the Lagoa Hospital, in the convergence of two districts - Jardim Botânico and Lagoa - followed the 1950s and 1960s urbanization process in the Southern area of the city of Rio de Janeiro, with the rise of real estate value and the removal of low-income land occupations.

23 Niemeyer used the 'V' shape pillar in many of his buildings, such as: the California Building, in São Paulo (1951); the Agriculture Palace (1951-1954), in São Paulo; the Lagoa Hospital (1952), in Rio de Janeiro; the Getúlio Vargas Foundation, in Rio de Janeiro (1955); Apartament Buildings in Berlin (1954); and the JK Building, in Belo Horizonte (1951), this one with 'W' shape version (Costeira 2016). 24 This building's authorship is unknown. 
ed by denser vegetation. This plaza, round in shape, seems to have been thought of as a place for meditation and contemplation of the landscape, marked by the skyline of the mountains. This was also the location chosen by the architect to place patients' wards and rooms, from where one can enjoy, besides adequate insolation, an open view and a sense of tranquillity that may contribute to their recovery.
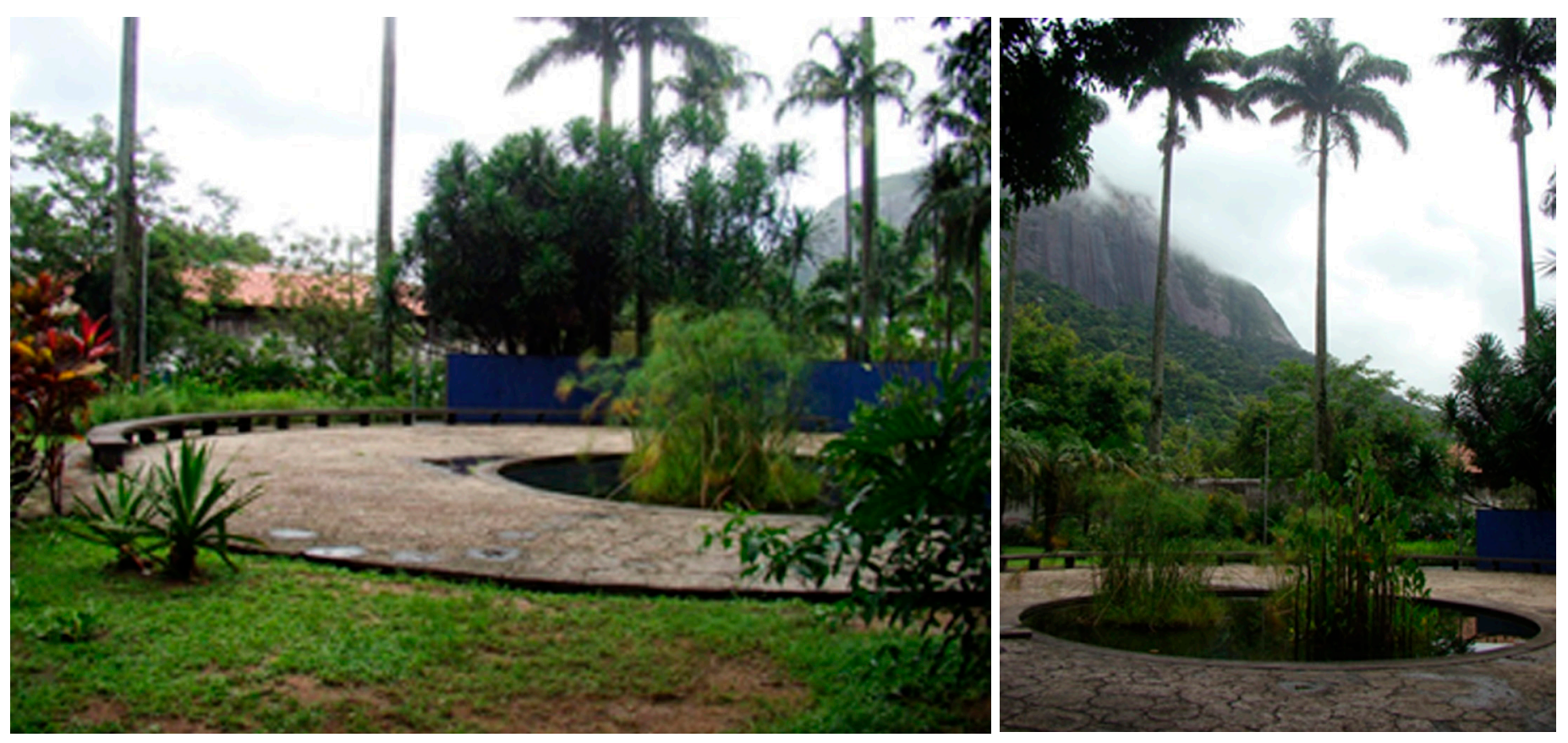

Figures 12 and 13. Round Plaza. LabLugares/PROARQ/FAU/UFRJ, 2013.

\section{The Souza Aguiar Hospital}

Finally, we will present the Souza Aguiar Hospital, which dates back to the 1960s, thus a later period. Although it was designed by an architect trained with the values of the 'Carioca School', the programmatic issues and the place where it was built were crucial for the decisions made by the author. Ary Garcia Roza (1911-1999), who graduated from ENBA in 1934 and maintained a close relationship with renowned colleagues such as Oscar Niemeyer, was considered a modest architect who described himself as having no vocation for exhibiting himself. But according to Jayme Wesley de Lima, although he did not think of himself as an artist, "Garcia Roza explains his values by arguing that architecture design is an aesthetic option, but that, above all, it is a necessary consequence of a correct interpretation of the program and the choice of the technique that best matches the function" (Lima 2012: pp.69). This qualifies Garcia Roza as more rationalistic than formalist due to his rigor and the use of multiple details in his architectural projects, aiming at constructability.

The project comprises several blocks with different functions - emergency, laboratory, hospital and blood bank. These buildings have replaced a previous structure, which equally functioned as a hospital and belonged to the same institution, founded in $1910^{25}$. The building site has a rare configuration in the city and it is situated in the central area, close to city transports, such as the train station named Brazil Central Station (Central do Brasil), which connects several neighborhoods as well as other municipalities within the metropolitan area. It is located in front of one of the early urban parks in Rio, the Republic Square (Praça da República) ${ }^{26}$, a historical area with

25 The Souza Aguiar Hospital is currently considered the largest emergency hospital in Latin America. It had its origin in an emergency service station in a different site of Rio de Janeiro city center that was created in 1908 during the administration of Mayor Pereira Passos. In 1910 it was transferred to its present address, to an eclectic style building, as the main general emergency hospital in the city. In 1955, it received its current name, and in the 1960s the old building was demolished to make way to the hospital complex with a project by architect Ary Garcia Roza.

26 Also called Santana Field (Campo de Santana), it marked the limits of the city with the rural area during the colonial period. In 1854, 
dense vegetation. A small lot of land for an extensive program to assist a large number of people resulted in the concentration and verticalization of the buildings, with little space for gardens.

The main entrance of the Souza Aguiar Hospital, used by visitors and patients, stands at the street along the Republic Square, on the left side of the hospital site. Architect Garcia Roza created a route, an architectural promenade, in which elements as courtyards, vertical gardens, wall panels and a circular shaped chapel contrast with the ensemble's orthogonality.

We must emphasize the vertical garden, planned by landscape designer Burle Marx in the 1960s, which, in addition to marking the entrance, intermediating the hospital complex with the neighboring building, creating a concrete and vegetated wall with voids that makes it possible to see vestiges of the old building.

Completing this pathway, to the right, on the outside of the building, there is the chapel; and to the left, the entrance hall of the hospital block. This hall is marked by a work of great plastic effect, a mural panel also by Burle Marx. This panel (4m x 20m), unlike many others of the artist, was not made in tiles, but in semi-precious Portuguese stones. The composition of abstract and marked shapes is described by Rubens de Andrade and Jane Santucci (2009: 118) as follows:

plastically articulated by an asymmetrical composition where the artist materializes, in geometric and organic forms, or in straight lines and curves, a dynamic drawing that gains greater intensity due to the marked chromatic opposition determined by the raw materials that compose the work.

These authors also report that Burle Marx opted for the semi-precious stones - rose quartz, white quartz, and amethyst -, not only because of their beauty, but also since it they had been attributed healing properties, although not scientifically proven.

In the ensemble of elements that compose this promenade, which was conceived in a context of integration of arts and architecture, the vertical garden is the one in the worse state of conservation. This idea of a vertical garden was used in other projects of Burle Marx; presently it no longer has its original plant species, the running water in the shape of a cascade that gently descended from a height of 5 meters, and the small pond that received the cascading water. Furthermore, changes have occurred in the original facade of the hospital building that have affected the conceived relation between the building and the garden, invalidating the proposed integration of architecture and landscaping in the reception area - the main entrance - for hospital's users.

\section{Final remarks}

As partial conclusions of this ongoing research, in which we have observed the presence of gardens and works of art, mainly murals, in modern hospitals designed by the 'Carioca School' architects between 1940 and 1960, we have analyzed a series of factors and we have presented some hypotheses throughout the text.

One of the hypotheses is the existence of a landscaping tradition in the city of Rio de Janeiro, which in a way was associated to the conception of the modern public building as representative of the State, the Nation, and the Modernity, a goal to be achieved in several political conjunctures between 1930 and 1960.

Lucio Costa's leadership in the field of the modernization of architecture, who had been seeking national expression in architecture since the 1920s, supports the idea of a tropical architecture that valued a re-appropriation of elements of the Portuguese colonial architecture and the integration of the arts, and it aimed at a significant change in the teaching of architecture towards modernity.

the first urban railway station of Brazil, then named Dom Pedro II Station, was built nearby. Between 1873 and 1880 , a public garden was built with landscaping by French landscape designer Auguste François Marie Glaziou. In 1941, the current Brazil Central Station was inaugurated at the old station's site. 
On the other hand, the debate and specific bibliography on hospital issues were present in the academic environment. This became a working area for architects who graduated after 1930 and found in the State apparatus wide conditions to express their professional practice using the skills acquired during their architecture course.

Both the symbolic and functional aspects of public buildings were considered by these architects as part of the architectural project, into which the garden and the arts were integrated, aiming at creating a space that could be both representative of the State and the country's modernization. The location and the articulation with the hospitals' surroundings were also taken into consideration in the buildings' implementation and the landscaping design. These aspects would provide better conditions for the welcoming and permanence of users and staff in the hospitals.

The paths and views from the places that interweaved gardens and works of art, as well as highlighted volumes, were thought from the perspective of the buildings' programs, reconciling the 'physiological functional' aspects with the 'functional plastic' (Amora and Souza 2016: 4), that is, considering the plasticity in which the architectural form, the gardens and the works of art are presented as part of the function of the hospital building, thus contributing to the healing of the sick and the well-being of the staff.

\section{REFERENCES}

ANDRADE, Rubens de and SANTUCCI, Jane (2009), De pedras e jardins: a conjunção paisagistica de Burle Marx no hospital Souz̧a Aguiar, Rio de Janeiro: Leituras paisagísticas, UFRJ, pp. 104-121.

AMORA, Ana M. G. A. and SOUZA, Eliara B. (2016), IPPMG: obra exemplar, sintese das artes, de Jorge Machado Moreira, Recife: XI Seminário Docomomo, http://seminario2016.docomomo.org.br/

BARBOZA, Luiz H. and MOREIRA, Jorge Machado (1952), "Instituto de Puericultura", Revista do Serviço Público, Rio de Janeiro: DASP - Serviço de Documentação, pp. 123-157.

BRITO, Samuel Silva de (2014), Lucio Costa: o processo de uma modernidade. Arquitetura e projetos na primeira metade do século XX, $\mathrm{PhD}$ Thesis on Architecture presented to the Universidad Politecnica de Catalunya.

CAIUBY, Adelardo Soares (1919), Projecto da leprosaria modelo nos campos de Santo Ângelo estado de São Paulo. São Paulo: Gráfica E. Riedel \& C.

CAMARGO, Mauro Álvaro de Souza (1930), Hospitaes, São Paulo: Escolas Profissionais Salesianas.

CARDOSO, Vicente Licinio (1930), I - A margem das architecturas grega e romana; II - Principios geraes modernos de bygiene hospitalar e sua aplicação no Rio de Janeiro (Theses apresentadas no concurso para provimento da cadeira "architectura civil" na Escola Polytechnica (Universidade do Rio de Janeiro), Rio de Janeiro: Typographia do Annuario Brasil.

COSTA, Renato da Gama-Rosa et al. (2002), O sanatório de Curicica: Uma obra ponco conbecida de Sérgio Bernardes, São Paulo: Vitruvius, Architexto. http://www.vitruvius.com.br/revistas/read/arquitextos/03.026/766

CZAJKOWSKI, Jorge Paul ed. (1999). Jorge Machado Moreira. Rio de Janeiro: Centro de Arquitetura e Urbanismo do Rio de Janeiro.

FERREIRA, Alda de Azevedo et al. (2017), "A institucionalização do ensino de arquitetura paisagística no Rio de Janeiro", Paisagem e ambiente: ensaios, São Paulo: n. 40, pp.133-148.

GIDEON, Sigfried (1958), Architecture, you and me. The diary of a development, Cambridge: Havard University Press.

INSTITUTOS DE ARQUITETOS DO BRASIL ed. (1954). Planejamento de Hospitais, São Paulo: IAB. 
LIMA, Jaime Wesley de (2012). O patrimônio bistórico modernista: Identificação e valoração de edifício não tombado de Brasilia -O caso do edificio sede do Banco do Brasil, Master Thesis on Architecture and Urbanism presented to the University of Brasilia, Brasilia.

RODRIGUES, Ana L. de Mello et al. (ed.) 2013. Instituto de Puericultura e Pediatria Martagão Gesteira: 60 anos. Rio de Janeiro: Universidade Federal do Rio de Janeiro.

STEVENS, Edward F. (1918), The American hospital of the twentieth century, New York: Architectural Record.

XAVIER, Alberto ed. (2003). Depoimentos de uma geracão: arquitetura moderna brasileira, São Paulo: Cosac \& Naify. 